\title{
Stakeholders' Perspective on the Implementation of Train Law in Cebu City, Philippines
}

\author{
Charito Bonghanoy ${ }^{1}$, Jonathan O. Etcuban ${ }^{2}$, Nina Lyn Bueno ${ }^{3}$, Gerwine Medio ${ }^{4}$, \\ Reylan Capuno and Dennis Capuyan ${ }^{6}$ \\ ${ }^{1 \& 3}$ Faculty, University of Cebu, ${ }^{2,4,5 \& 6}$ Faculty, Cebu Technological University \\ E-Mail: charitobonghanoy812@gmail.com, joetcuban@gmail.com, buenoninalyn36@gmail.com
}

\begin{abstract}
The Tax Reform for Acceleration and Inclusion (TRAIN) is the principal bundle of the Comprehensive Tax Reform Program (CTRP) imagined by the Duterte organization to address insufficiencies in the duty framework making it less complicated, more pleasant, and a progressively proficient assessment framework yet draws heap of responses from different segments in the economy especially the shoppers and the regular workers. This study assessed the effect of the imposition of TRAIN Law as viewed by the various sectors in the local economy of Cebu City specifically from four sectors: non-working, employees from the public, employees from private, and micro-entrepreneurs. This study employed a descriptive method of research using a researcher-made questionnaire. The respondents comprising of the non-working sector, the employee from the public sector, the employee from the private sector, and micro-entrepreneurs. It was conducted in Cebu City with 20 villages that were surveyed using a random sampling method. Frequency, simple percentage, weighted mean, Chi-square test of independence, and ANOVA were used to treat the gathered data.The study revealed that the effect on the imposition of TRAIN Law towards the consumers was moderately evident in terms of the affordability of the necessary goods and services, social overhead capital and infrastructure, and the development of micro-enterprises, while in terms of the affordability of non-essential commodities and disposable income, the effect or impact as only slightly evident. It was concluded that despite the assessment on the full effect of TRAIN in various dimensions of the economy is still premature since the implementation was still at the first package; the people still perceived that there is already an apparent improvement in the delivery of public services and infrastructures.
\end{abstract}

Keywords: Business Management, Tax Law, Descriptive Method, Philippines

\section{INTRODUCTION}

The Philippine President signed into lawa tax reform package known as TRAIN programon December 2017. The Philippines has one of the most astounding VAT rates and the most astounding number of exceptions in the Southeast Asia area (Olz\&Beerepoot, 2010; Asher \&Rajan, 2001). The duty program redesigns the nation's 20-year-old assessment routine in an offer to make the expense framework more attractive and increasingly direct. The TRAIN law is the primary bundle of the CTRP to address a few inadequacies in the duty framework to make it less stressful, more attractive, and increasingly useful to support the government's plan on raising the bulk of needed funds for the Duterteadministration's ambitious infrastructure drive,"Build, Build, Build" program.

Taxation imposes and demand contribution upon persons, properties, or rights to generate revenues for public purposes (Murphy \& Nagel, 2002). The power of the state rests upon necessity and is inherent for every government or sovereignty (Goodnow, 2017). The power of taxation is legislative and essential to the existence of an independent government (Talmadge, 2000). It is based upon the theory that no government or state canstand without taxes (Luciani, 2015).

Surveys show that a significant factor for the reduced tax collection is the apparent unawareness of most taxpayers of existing laws, rules and regulations (McKerchar\& Evans, 2009). Taxes are increasingly both in rate and variety, and it becomes even more pressing to push effective dissemination of information on taxation that will permeate all strata of the society for they will share of tax burden (Dore, 2013; Bozeman, 2007; Bank, 2002).

One of the leading proponents of TRAIN Law in Congress described the law as skillfully crafted for it taxes the rich more while providing social mitigation measures to protect the poor from its temporary inflationary impact. The law is one of the best defensible public policy instruments in the history of this country. It is the most viable tool to force the country closer to its national goal of becoming a progressive, more inclusive economy.

In the midst of calls by a few legislators to suspend a few arrangements in the duty change bundle to help cut swelling rates down, the Budget Secretary says doing as such would accomplish more damage than anything else to the economy. Suspending the TRAIN Act would disturb activities at the Bureau of Internal Revenue (BIR) and the Bureau of Customs (BOC). These two organizations have effectively forced the new expense rates and connected their objective accumulations dependent on the law. Account authorities likewise cautioned that the administration's foundation program and the nation's financial development would endure if the extract charge accumulations were suspended. 
In this context, it is just imperative that the imposition of the tax above system must be studied to draw a proposed training module to address the effect of the newly implemented TRAIN law in the Philippines.

\section{OBJECTIVES OF THE STUDY}

This study determined the effect on the imposition of TRAIN Law to the various sectors in the local economy of Cebu City.The findings were used as the basis for proposing a training module to address the effect of TRAIN Law.It addressed the:

1. Profile of the respondents;

2. Effect of the imposition of TRAIN Law to the consumers under the following dimensions: Affordability of the necessary goods and services, Affordability of non-essential commodities, Social overhead and infrastructure, Disposal income, and Development of microenterprise;

3. Significant degree of relationship between the profile of the respondents and their perception of the effect of the imposition of TRAIN Law; and

4. Significant degree variance among the respondents on the effect towards the imposition of TRAIN Law.

\section{METHODOLOGY}

This study applies the mixed research method. This study used the researcher-made questionnaire and interview guide as the primary tool for data gathering. The participants of this study were the various takeholders of CebuCity, comprising of the non-working sector, the employee from the public sector, the employee from the private sector, and micro-entrepreneurs. There was also an interview on selected stakeholders of the TRAIN Law to determine the real change or effect of its imposition.

This study was conducted in CebuCity. It is atop of the line very urbanized city in the island regionof Cebuin Central Visayas, Philippines. The populace it starting of 2015Census was 922,611, making it the fifth most populated city in the country and the most crowded in the Visayas. CebuCity is a strong focal point of business, exchange and training in the Visayas. It is located on the mid-eastern side of CebuIsland, Philippines.

The respondents of the study were the various consumers in Cebu City who were affected by the imposition of TRAIN Law. Random selection was applied in determining the respondents. There were 458 informants from the various stakeholders in the society to share their knowledge on the effect of the TRAIN Law taken from the non-working group, employees from public sectors, employees from private sectors, and micro-entrepreneurs. For the quantitative survey, the researcher surveyed 20 barangays with five rural and fifteen urban barangays. The questionnaires were distributed approximating the SWS survey methodology. Each barangay has proponents of five respondents for every sector.
TABLE I RESEARCH RESPONDENTS

\begin{tabular}{|l|c|c|c|c|}
\hline \multicolumn{1}{|c|}{ Sector } & $\begin{array}{c}\text { Urban } \\
\text { Area }\end{array}$ & $\begin{array}{c}\text { Rural } \\
\text { Area }\end{array}$ & Total & $\%$ \\
\hline Non-working group & 81 & 29 & 110 & 24 \\
\hline $\begin{array}{l}\text { Employees from } \\
\text { public sectors }\end{array}$ & 96 & 16 & 112 & 24 \\
\hline $\begin{array}{l}\text { Employees from } \\
\text { private sectors }\end{array}$ & 80 & 34 & 114 & 25 \\
\hline Micro-enterprises & 97 & 25 & 122 & 26 \\
\hline Total & 354 & 104 & 458 & 100 \\
\hline
\end{tabular}

The researcher-developed a survey tool to gather responses on the two aspects of the study. The first aspect pertains to the profile of the respondents regarding age, gender, civil status, number of dependents, and average monthly income level. The second aspect determines the effect of the imposition of TRAIN Law to the consumers regarding the affordability of the essential goods and services, affordability of non-essential commodities, social overhead and infrastructure, disposal income; and development of micro-enterprise/vendors. The basis of the study was based on the theory of optimal taxation theory and supported by the review of related literature. The respondents were made to check under the column that corresponds to answers for each given item. The survey questionnaire is researchermade. Retrieval of the said instruments was made after tendays. The accomplished questionnaires were collected, and the results were tallied and tabulated. The incidence of non-response on every question and the trend of responses were noted.The gathered datawere statistically treated using frequency, simple percentage, mean, Chi-square test of independence, and ANOVA.

\section{RESULTS AND DISCUSSIONS}

\section{A. Profile of the Respondents}

The data contained in Table II show the profile of the respondents who come from the various sectors of the economy in terms of age, gender, civil status, number of dependents, average monthly income, place of residence, and sector.

Table II reveals that more respondents were at the age range within 26-30 years old, have 1-3 dependents per household, and earned within Php 7,890.00 to Php 15,780.00 per month. Majority of the respondents were females and were married.

Under the Philippine law, the minimum wage earners in Region \& including Cebu city earn within this income bracket. Under the 2012 family Income and Expenditure (FIES), those who earned this level of income are those considered as low-income earners but not weak, wherein the per capita income between the poverty line and twice the poverty line (Albert et al., 2015). This income level is the most common earning level for the ordinary workers in Cebu City. It can be noted that two respondents earned at a 
range of Php 118,350-157,800.00 per month. Those who earned this level are for those earners who are considered at the upper income (but not rich, where the per capita income between fifteen times the poverty line and twenty times the poverty line.

TABLE II PRofiLE Of THE RESPONDENTS

\begin{tabular}{|l|c|c|}
\hline \multicolumn{3}{|c|}{ A. Age (in years) } \\
\hline $18-21$ & 28 & Percentage \\
\hline $22-25$ & 53 & 11.57 \\
\hline $26-30$ & 81 & 17.69 \\
\hline $31-35$ & 63 & 13.76 \\
\hline $36-40$ & 47 & 10.26 \\
\hline $41-45$ & 67 & 14.63 \\
\hline $46-50$ & 57 & 12.45 \\
\hline $51-55$ & 25 & 5.46 \\
\hline $56-59$ & 18 & 3.93 \\
\hline 60 and above & 19 & 4.15 \\
\hline Mean : & 37.55 & \\
\hline StDev : & 11.96 & \\
\hline \multicolumn{3}{|c|}{ B. Gender } \\
\hline Female & 302 & 65.94 \\
\hline Male & 156 & 34.06 \\
\hline \multicolumn{2}{|c|}{173} & 37.77 \\
\hline Married & 21 & 4.59 \\
\hline Single & 264 & 57.64 \\
\hline Separated & \multicolumn{2}{|c|}{} \\
\hline
\end{tabular}

\begin{tabular}{|l|c|c|}
\hline \multicolumn{3}{|c|}{ D. Number of Dependents } \\
\hline 0 & 57 & 12.45 \\
\hline $1-3$ & 304 & 66.38 \\
\hline $4-6$ & 82 & 17.90 \\
\hline More than 6 & 15 & 3.28 \\
\hline Mean : & 2.00 & \\
\hline StDev : & 1.86 & \\
\hline \multicolumn{2}{|c|}{ E. Average Monthly Income (in Php) } \\
\hline Less than 7,890 & 90 & 19.65 \\
\hline $7,890-15,780$ & 177 & 38.65 \\
\hline $15,780-31,560$ & 139 & 30.35 \\
\hline $31,560-78,900$ & 43 & 9.39 \\
\hline $78,900-118,350$ & 4 & 0.87 \\
\hline $118,350-157,800$ & 2 & 0.44 \\
\hline
\end{tabular}

\section{B. Effect of the Imposition of TRAIN Law to the Consumers}

The first of five expense change bundles for a less rigorous, reasonable, and practical assessment framework. For all time, TRAIN brings down close to home pay charge, disentangles the domain and giver's expense, and extends the VAT run. Then again, it builds extract assesses on fuel, mineral items, vehicles, and cigarettes. It likewise forces new assessments on sugar-improved refreshments and corrective methodology.

The first aspect that is being determined in this investigation is whether the imposition of TRAIN Law affects the number of goods that can be bought by consumers.

TABLE III EFFeCt Of Train LaW As To AfFordability Of Basic Goods AND SERvices

\begin{tabular}{|ll|c|c|}
\hline \multicolumn{1}{|c|}{ Indicators } & $\begin{array}{c}\text { Weighted } \\
\text { Mean }\end{array}$ & Interpretation \\
\hline 1. & $\begin{array}{l}\text { Fuel, gasoline, and cooking gas have become } \\
\text { more expensive to buy for mass consumers. }\end{array}$ & 3.16 & Moderately Evident \\
\hline 2. & My family can buy medicines and other medicinal commodities. & 2.79 & Moderately Evident \\
\hline 3. $\quad \begin{array}{l}\text { Goods such as canned goods, poultry, meat, eggs, fish, beverages, } \\
\text { water, and processed foods can be bought on more quality. }\end{array}$ & 2.76 & Moderately Evident \\
\hline 4. $\quad$ The cost of electricity, water, and other utilities is still affordable. & 2.64 & Moderately Evident \\
\hline 5. $\quad \begin{array}{l}\text { My family can still afford to pay tuition fee and have more } \\
\text { access to quality education from the primary, secondary, and tertiary level. }\end{array}$ & 2.59 & Moderately Evident \\
\hline Aggregate Mean & 2.79 & Moderately Evident \\
\hline
\end{tabular}

The data contained in Table III show that the weighted of 3.16 reveals that the imposition of TRAIN Law causes fuel, gasoline, and cooking gas to become more expensive for the mass consumers and the effect was moderately evident. Among the items in this indicator, item number 2 obtained the highest weighted mean. The continuous increase in the prices of these goods in the market at the time of the study decreases the ability of the consumers to purchase enough amount or quantity of goods for their daily household consumption requirement. This means that the additional tax decreases the purchasing power of the consumers' income.

On the other hand, the lowest mean of 2.59 indicates that it was moderately evident also that the family can still afford to pay tuition fee and have more access to quality education from primary, secondary, and tertiary level. This indicates that the effect of the imposition of TRAIN affects the cost of education in Cebu City was only in many instances. So, it cannot be denied that the there was indeed a subsequent 
increase of the school fees as an effect of the imposition of TRAIN Law since the school is also a business entity that has to survive, and they are exempted from taxes, although the rates vary from other types of taxes that are subjected to other businesses. However, the family can still send their children to school since most of the Filipinos give value to education.

Moreover, the aggregate mean of 2.79 indicates that the effect of the imposition of TRAIN Law towards the affordability of the necessary goods and services was moderately evident towards the consumers. This identifies with the way that the burden on taxes to other goods like fuel causes the prices of all essential commodities that are sold in the market to increase. However, despite the expected inflation of the various commodity items, the consumers responded that they can still afford to buy food items, medicines, utilities and education since these are the priority items in every income level. So the demand elasticity is in elastic. There are considerably more noteworthy changes under the Train law, which is not being accounted for. Train moderately diminishes the expense on close to home pay, bequest, and gift. Be that as it may, it additionally builds the assessment on certain latent livelihoods, narrative stamp charge) just as an extract charge on oil-based commodities, minerals, autos, and cigarettes.

TABLE IV EFFECT Of Train LAw As To As To AFFORDABILITy OF NON-ESSENTIAL COMMODITIES

\begin{tabular}{|l|c|c|}
\hline \multicolumn{1}{|c|}{ Indicators } & $\begin{array}{c}\text { Weighted } \\
\text { Mean }\end{array}$ & Interpretation \\
\hline $\begin{array}{l}\text { 1. I can buy expensive electronic products such as cellular phones, } \\
\text { Tablets/iPods, laptops, and other electronic products. }\end{array}$ & 2.29 & Slightly Evident \\
\hline $\begin{array}{l}\text { 2. } \\
\text { can be afforded for a consumer like me. }\end{array}$ & 2.13 & Slightly Evident \\
\hline 3. I can buy signature bags, shoes, and other accessories of high value. & 2.06 & Slightly Evident \\
\hline 4. Traveling to other places for vacation and leisure has become my hobby. & 2.05 & Slightly Evident \\
\hline 5. I can afford to buy vehicles like a car, expensive motorcycles. & 1.96 & Slightly Evident \\
\hline Aggregate Mean & 2.10 & Slightly Evident \\
\hline
\end{tabular}

The highest weighted mean of 2.29 indicates that it was slightly evident that the imposition of TRAIN law has affected in the context of the consumers' can buy expensive electronic products such as cellular phones, tablets/iPods, laptops, and other electronic products. This means that such things are not basic for some consumers but find it necessary for communication, and entertainment. The lowest mean of 1.96 indicates that it was slightly evident that the imposition of the TRAIN Law has an effect on the consumers' expenditures on affordability to buy vehicles like a car and expensive automobiles. In the law, cars and expensive automobiles are affected because of the excise tax imposed. Thus it will be expected to the increase in prices of such commodities. However, at the time of the study, the imposition of the law mentioned above was still at the first package, wherein the excise tax on vehicles had not been fully implemented. Just, recently the second package on the imposition was put on hold due to the fear of more inflation in the market and evaluates the value of the Philippine peso.

TRAIN rearranges the extracted charge on vehicles. However, lower-estimated autos keep on being saddled at lower rates while progressively expensive autos are exhausted at higher rates. This extract will bring income up in a dynamic way as the more well-off purchasers keep an eye on claim more and costly vehicles contrasted with the individuals who acquire less.

TRAIN builds the extract of oil-based goods, which has not been balanced since 1997. The non-indexation of the fuel extract expense to expansion has disintegrated the incomes gathered by P140 billion every year in 2016 costs. Fuel extract is wrongly seen to be against the poor. This is a duty that will influence the rich unquestionably more than poor people, given their more noteworthy oil utilization than poor people.

Moreover, the aggregate mean of 2.10 indicates that the effect on the imposition of TRAIN Law was only slightly evident, as perceived by the consumers. This means that the effect of the imposition of TRAIN Law was not being felt in the purchase of the non-essential commodities, because the imposition was still at the first package and other excise taxes has not been entirely imposed on specific goods. The TRAIN Law has expanded the earnings or spending capacity of the Filipino, especially the Cebuano shoppers or consumers in Cebu City. They now have the propensity to purchase more inferior goods. One constructive outcome of high monetary development is an ascent in local interest or utilization, which, be that as it may, prompts a brief spike in the expansion. The beneficial thing, however, is the higher incomes produced by the TRAIN has empowered the legislature to set up different measures.

Roads and bridges, better technology increase in efficiency are preconditions for development, but they are never wanted for their own sake. They are only meant towards something else- to provide more and more people with more and better things and opportunities. The provision for social overhead capital like roads, bridges, railroads, airports, communications system and provision of the more efficient production process are very much needed because the result and objectives for which are built for the welfare of man. 
TABLE V EFFECt Of Train LAW As To SOCIAL OVERHEAd CAPITAL AND INFrastructure

\begin{tabular}{|c|c|c|}
\hline Indicators & $\begin{array}{l}\text { Weighted } \\
\text { Mean }\end{array}$ & Interpretation \\
\hline $\begin{array}{l}\text { 1. Improvement to public utilities and education } \\
\text { is visible and accessible to all Filipino people. }\end{array}$ & 2.78 & Moderately Evident \\
\hline $\begin{array}{l}\text { 2. The general welfare of children, women, destitute, victims of crimes both in } \\
\text { government organizations gives other marginalized groups priority attention. }\end{array}$ & 2.68 & Moderately Evident \\
\hline $\begin{array}{l}\text { 3. Public goods like roads, highways, bridges, streetlights, } \\
\text { and flyovers are available to all and are in good functional condition. }\end{array}$ & 2.66 & Moderately Evident \\
\hline $\begin{array}{l}\text { 4. The services of the government agencies } \\
\text { are productive and give us satisfaction }\end{array}$ & 2.60 & Moderately Evident \\
\hline $\begin{array}{l}\text { 5. The services of government agencies are productive and } \\
\text { give us satisfaction and contentment. }\end{array}$ & 2.59 & Moderately Evident \\
\hline Aggregate Mean & 2.66 & Moderately Evident \\
\hline
\end{tabular}

The weighted mean of 2.78 indicates that the effect on the imposition of TRAIN law towards the consumers was moderately evident in the context of the visibility and accessibility to all Filipino people on the improvement of public utilities and education. It only shows that due to the revenues collected by the government from the imposition of the excise taxes on many commodities and transactions, the respondents assessed that there is an apparent improvement on essential governmental services that were provided to the citizens, especially on building public roads, bridges, and other infrastructures as well as the economic and social welfare services. The expense change program is the focal bit of the administration's arrangement to raise the central part of the required assets for the Duterte organization's aspiring framework drive.

Additionally, the lowest weighted mean of 2.59 signifies that the respondents perceived the effect on the imposition of TRAIN Law as moderately evident in the framework of the productivity, satisfaction, and contentment brought about by the services provided by the government agencies.
This result can be inferred that the increase in the taxes being imposed by the government raises more revenues to fund the different projects and programs under the Duterte administration. The data indicate that there had been some improvements on the services provided by the government towards the people from the various sectors of the economy since it is inevitable that the public will always be affected by the government's role in the economy and the society as a whole. Moreover, the aggregate means of 2.66 means that the effect on the imposition of TRAIN Law towards the consumers was moderately evident or in many instances.

The purpose of TRAIN Law was to fund the "Build buildbuild" program of the Duterte government. The Duterte administration's twin pillars for economic inclusion - the Comprehensive Tax Reform Program and massive infrastructure build up under its "Build, Build, Build" initiative - will produce an insurgency in the nation's financial improvement and raise per-capita salary to the dimension of high-center pay economies by 2022 .

TABLE Vi EfFect Of Train LaW As To Disposable INCOME

\begin{tabular}{|l|c|c|}
\hline \multicolumn{1}{|c|}{ Indicators } & $\begin{array}{c}\text { Weighted } \\
\text { Mean }\end{array}$ & Interpretation \\
\hline 1. Income is not enough to support my family's basic needs and wants. & 2.60 & Moderately Evident \\
\hline 2. Per capita income has increased and felt by each people in the economy. & 2.38 & Slightly Evident \\
\hline 3. Income is more than enough to buy basic needs and wants. & 2.30 & Slightly Evident \\
\hline 4. Excessive income is invested in profitable securities or save it to the bank. & 2.16 & Slightly Evident \\
\hline 5. Excessive income is spent on luxury activity and leisure. & 1.90 & Slightly Evident \\
\hline Aggregate Mean & 2.27 & Slightly Evident \\
\hline
\end{tabular}

The highest weighted mean of 2.38 points out that respondents perceived that it was slightly evident that the imposition of TRAIN Law indicates that the per capita income has increased and being felt by each people in the economy. Although one of the features of this law is to decrease the PIT, to increase the disposable income of the income earners, but such increase on the purchasing capacity of the consumers creates more demand for goods and services and subsequently increases the prices of these commodities. So, the bottom line is that the purchasing power of the people even decreased due to the increased disposable income.

On the other hand, the lowest mean of 1.90 signifies that the respondents answered that it was slightly evident that the excessive income was spent on luxury activity and leisure. This result indicates that the increase in the disposable income had not increased the ability of the people or consumers to undertake luxury and leisure activity despite the increase in their net pay due to the decrease in the personal income tax. However, other items in consumption 
also become expensive. So, still, their affordability had not significantly improved at all.

Further, the aggregate mean of 2.27 indicates that the consumers perceived that it was only slightly evident that the imposition of legislation above had increased the purchasing ability or the real income of the consumers, especially the Cebuano consumers. This result only means that decreasing the personal income tax will not increase the purchasing power of the people if there is no corresponding improvement in the productive capacity of the economy in producing better goods and services for the people and by the people. That means that production should take place within the domestic economy, not from other countries since, at the moment, the economy is dependent on importing goods from other countries.

\section{Effect on the Imposition of TRAIN Law to the Personal Income Tax}

Another critical aspect that is being assessed in this study is the effect of the imposition of the Personal Income Tax. One of the main features of TRAIN Law is to amend and simplify the complex personal income tax system. Income tax contributes revenue, and the broadening of the income tax base increases dependable source of revenue to the government.

The PIT rates for $99 \%$ of taxpayers were reduced after the TRAIN law took effect. The imposition of the TRAIN is to increase taxpayers' disposable income. Disposable income is personal income available for consumption after excluding personal taxes. When personal income tax is decreased, then there is a subsequent increased in the disposable income of the people whose course of income comes from compensation.

A less stressful, more attractive, and more effective duty framework is expected to advance speculation, make occupations, and diminish destitution. Not changing the duty framework will deny the poor of the vital social administrations and foundation that can lift them out of destitution and make them more gainful supporters of society. By making the assessment framework less complicated, more attractive, and more proficient, extra and a more feasible stream of incomes should be produced to make important speculations on our foundation to accomplish our vision for the Philippines.

TABle ViI EFFect Of Train Law As To DeVelopment Of Micro-EnTERPRise

\begin{tabular}{|l|c|c|}
\hline \multicolumn{1}{|c|}{ Indicators } & $\begin{array}{c}\text { Weighted } \\
\text { Mean }\end{array}$ & Interpretation \\
\hline $\begin{array}{l}\text { 1. Imposed taxes from the government affect the cost and price } \\
\text { 2. of the goods and services. }\end{array}$ & 3.33 & Moderately Evident \\
\hline 3. Microenterprise helps create more jobs for Filipino people. & 2.78 & Moderately Evident \\
\hline $\begin{array}{l}\text { 4. Microenterprise helps to improve and innovate products } \\
\text { 5. and services in the local economy. }\end{array}$ & 2.71 & Moderately Evident \\
\hline $\begin{array}{l}\text { 6. Microenterprise produces a good quality product beneficial } \\
\text { 7. to society's needs and wants. }\end{array}$ & 2.69 & Moderately Evident \\
\hline 8. Products and services are sold to the market are in fair price. & 2.46 & Slightly Evident \\
\hline Aggregate Mean & 2.79 & Moderately Evident \\
\hline
\end{tabular}

The weighted mean of 3.33 indicates that it was moderately evident that the imposed taxes from the government affect the cost and price of the goods and services that the microenterprises offered to the consumers. This item obtains the highest mean in this indicator. This result entails the microentrepreneurs to make the necessary adjustment to their pricing on the goods and services that they offer to the consumers. This decision is very critical since if the enterprise owners imposed high prices, it would have a profound impact on the demand of those commodities and thereby affecting also their profitability.

On the other hand, the lowest mean of 2.46 signifies that it was only slightly evident that the products and services that are sold to market are at a fair price. So, this means that the imposition of TRAIN law causes the prices of the commodities to increase and consumers can also afford lesser quantity despite the increase in their disposable income due to the decreased personal income tax. Finally, the aggregate mean of 2.79 signifies that the respondents answered that the effect of the imposition of TRAIN Law was only moderately evident. So, this means that any of the respondents only observed the effect of the abovementioned law towards the prices of the goods, as well as towards the role of the micro-enterprises towards the economy was just in many instances only. This means that there are still many aspects or facets of the operations of the small businesses that need to be assessed on whether the TRAIN is beneficial to them or not.

The statutory requirement of a tax indicates who is legally responsible for it. However, the situations differ drastically concerning who indeed bears the burden. Prices change in response to the tax, knowledge of statutory requirements tells virtually nothing about who pays the tax. In contrast, the economic condition of a tax is the change in the distribution of real private income induced by taxes. People should be classified for purposes of incidence analysis on how they can bear taxes. Often the role in production - what inputs people supply to the production process is used. Similarly, some people own substantial capital and work full-time. Thus, it is more relevant to study how taxes affect 
the way total income is distributed among people and the size distribution of income.

Ensuring economic growth is wide-based, and decreased neediness has turned into a critical improvement challenge. In numerous nations, destitute individuals cannot wholly take an interest in or appreciate the advantages of, commercial development. Destitute individuals, especially the poor people, in creating scene frequently need access to safe spots to keep their funds. They cannot get credit to begin organizations or to develop their organizations or homesteads. The poor regularly do not have essential administrations like protection to secure themselves against dry season and catastrophic events. Little and little firms claimed by the poor frequently have little help in gaining admittance to new advances or business organizes that could enhance chances to move their items.

\section{Results on the Test of Significant Relationship}

Table VIII presents the results on the test of the significant relationship between the profile of the respondents and their perception on the effect of the imposition of TRAIN Law towards the consumers.

Table ViII Relationship Between Profile Of The Respondents And Their EfFect Of Train Law To The Consumers

\begin{tabular}{|c|c|c|c|c|c|}
\hline Variables & Chi-Square & df & cv & Significance & Result \\
\hline \multicolumn{6}{|c|}{ A. Age } \\
\hline Affordability of Basic Goods and Services & 24.617 & 27 & 40.113 & Not Significant & Ho Accepted \\
\hline Affordability of Non-Essential Commodities & 28.971 & 27 & 40.113 & Not Significant & Ho Accepted \\
\hline Social Overhead Capital \& Infrastructure & 34.432 & 27 & 40.113 & Not Significant & Ho Accepted \\
\hline Disposal Income & 39.875 & 27 & 40.113 & Not Significant & Ho Accepted \\
\hline Development of Micro-Enterprise & 36.014 & 27 & 40.113 & Not Significant & Ho Accepted \\
\hline \multicolumn{6}{|c|}{ B. Gender } \\
\hline Affordability of Basic Goods and Services & 1.307 & 3 & 7.815 & Not Significant & Ho Accepted \\
\hline Affordability of Non-Essential Commodities & 2.813 & 3 & 7.815 & Not Significant & Ho Accepted \\
\hline Social Overhead Capital \& Infrastructure & 3.469 & 3 & 7.815 & Not Significant & Ho Accepted \\
\hline Disposal Income & 0.359 & 3 & 7.815 & Not Significant & Ho Accepted \\
\hline Development of Micro-Enterprise & 2.506 & 3 & 7.815 & Not Significant & Ho Accepted \\
\hline \multicolumn{6}{|c|}{ C. Civil Status } \\
\hline Affordability of Basic Goods and Services & 9.272 & 6 & 12.592 & Not Significant & Ho Accepted \\
\hline Affordability of Non-Essential Commodities & 4.549 & 6 & 12.592 & Not Significant & Ho Accepted \\
\hline Social Overhead Capital \& Infrastructure & 6.023 & 6 & 12.592 & Not Significant & Ho Accepted \\
\hline Disposal Income & 11.871 & 6 & 12.592 & Not Significant & Ho Accepted \\
\hline Development of Micro-Enterprise & 2.917 & 6 & 12.592 & Not Significant & Ho Accepted \\
\hline \multicolumn{6}{|c|}{ D. Number of Dependents } \\
\hline Affordability of Basic Goods and Services & 13.021 & 9 & 16.919 & Not Significant & Ho Accepted \\
\hline Affordability of Non-Essential Commodities & 14.480 & 9 & 16.919 & Not Significant & Ho Accepted \\
\hline Social Overhead Capital \& Infrastructure & 10.276 & 9 & 16.919 & Not Significant & Ho Accepted \\
\hline Disposal Income & 9.009 & 9 & 16.919 & Not Significant & Ho Accepted \\
\hline Development of Micro-Enterprise & 13.956 & 9 & 16.919 & Not Significant & Ho Accepted \\
\hline \multicolumn{6}{|c|}{ E. Monthly Income } \\
\hline Affordability of Basic Goods and Services & 25.917 & 18 & 28.869 & Not Significant & Ho Accepted \\
\hline Affordability of Non-Essential Commodities & 48.337 & 18 & 28.869 & Significant & Ho Rejected \\
\hline Social Overhead Capital \& Infrastructure & 12.325 & 18 & 28.869 & Not Significant & Ho Accepted \\
\hline Disposal Income & 27.299 & 18 & 28.869 & Not Significant & Ho Accepted \\
\hline Development of Micro-Enterprise & 13.255 & 18 & 28.869 & Not Significant & Ho Accepted \\
\hline
\end{tabular}

Table VIII revealed that there is no significant relationship between the age of the respondents and their perception on the effect of the imposition of TRAIN law in the aspect of affordability of basic goods, affordability of non-essential commodities, social overhead capital and infrastructure, disposable income, and development of micro-enterprises. Also, there is also no significant relationship between the gender of the consumers and their responses on how TRAIN 
law affects them, based on the aspects above. Likewise, there is also no significant relationship between the civil status of the respondents, and their insights on the relative effect of the taxes levied based on the provisions of TRAIN law under the various aspects.Further, there is no massive connection between the respondents' number of respondents and their objectivity on the impact of TRAIN law towards them as purchasers. Be that as it may, there is a critical connection between the month to month salary of the respondents and their impression of the impact of TRAIN Law towards the moderateness of the insignificant wares.

\section{E. Results on the Test of Significant Difference}

Table IX presents the results on the test of significant differences or variance on the perception of the various respondents on the effect of the imposition of TRAIN Law towards the consumers.

TABle IX Significant Difference On The EFFECt Of Train Law To The Consumers

\begin{tabular}{|c|c|c|c|c|c|c|c|}
\hline Grouped By & df & \begin{tabular}{|c|} 
Sum \\
Square \\
\end{tabular} & \begin{tabular}{|c|} 
Mean \\
Square \\
\end{tabular} & $\begin{array}{c}\text { F- } \\
\text { value }\end{array}$ & $\begin{array}{c}\text { P- } \\
\text { Value }\end{array}$ & Significance & Results \\
\hline \multicolumn{8}{|c|}{ A. Age } \\
\hline Between Group & 53 & 12.931 & 0.244 & 1.19 & 0.184 & Not Significant & Ho Accepted \\
\hline Within Group & 404 & 83.039 & 0.206 & & & & \\
\hline Total & 457 & 95.970 & & & & & \\
\hline \multicolumn{8}{|c|}{ B. Gender } \\
\hline Between Group & 1 & 0.067 & 0.067 & 0.32 & 0.574 & Not Significant & Ho Accepted \\
\hline Within Group & 456 & 95.904 & 0.210 & & & & \\
\hline Total & 457 & 95.970 & & & & & \\
\hline \multicolumn{8}{|c|}{ C. Civil Status } \\
\hline Between Group & 2 & 0.473 & 0.237 & 1.13 & 0.325 & Not Significant & Ho Accepted \\
\hline Within Group & 455 & 95.497 & 0.210 & & & & \\
\hline Total & 457 & 95.970 & & & & & \\
\hline \multicolumn{8}{|c|}{ D. Number of Dependents } \\
\hline Between Group & 11 & 4.731 & 0.430 & 2.10 & 0.019 & Significant & Ho Rejected \\
\hline Within Group & 446 & 91.239 & 0.205 & & & & \\
\hline Total & 457 & 95.970 & & & & & \\
\hline \multicolumn{8}{|c|}{ E. Monthly Income } \\
\hline Between Group & 90 & 24.990 & 0.278 & 1.44 & 0.011 & Significant & Ho Rejected \\
\hline Within Group & 367 & 70.981 & 0.193 & & & & \\
\hline Total & 457 & 95.970 & & & & & \\
\hline
\end{tabular}

The table revealed that there is no significant difference in the respondents' age, gender, and civil status and their perception of the effect of TRAIN law towards them as consumers. This means that the perception of the respondents does not vary with regards to their current lifecycle stage, differences on the gender, and their marital status. Further, there is a significant difference in the perception of the respondents by their number of dependents and their level of monthly income. So, the insights of the respondent how the imposition of TRAIN affects their economic status differ on the number of people that consumes and how much the people in the household do earns.

\section{CONCLUSION}

The imposition of the TRAIN Law has drawn a multitude of skeptical reaction from the people. The observed effect was both desirable and undesirable towards the standard of life of the Cebuano consumers. The desirable effect of the legislative enactments relates to the increase in the purchasing capacity of the people due to the decrease in the personal income tax. However, the undesirable effect relates to the feeling of the stable and even worse living situation since the increase in income is countered by the increases in the prices of the goods and services, including the essential items.

The Philippine government should be transparent to the people on the salient provisions of the training law by conducting a different public awareness campaign to educate the people. Despite that assessment on the full effect of the train in various dimensions of the economy is still premature, since the implementation was still at the first package; the people still perceived that there is already an apparent improvement in the delivery of public services and infrastructures. 


\section{REFERENCES}

[1] Asher, M. G., \& Rajan, R. S. (2001). Globalization and tax systems: Implications for developing countries with particular reference to Southeast Asia. ASEAN economic bulletin, 119-139. Retrieved from https://goo.gl/BYQFMB.

[2] Bank, S. A. (2002). Corporate managers, agency costs, and the rise of double taxation. Wm. \& Mary L. Rev., 44, 167. Retrieved from https://goo.gl/Q3iDvm.

[3] Bozeman, B. (2007). Public values and public interest: Counter balancing economic individualism. Georgetown University Press. Retrieved from https://goo.gl/8ApQhS.

[4] Dore, R. (2013). Land reform in Japan. A\&C Black. Retrieved from https://goo.gl/QVCo4J.

[5] Goodnow, F. J. (2017). Politics and administration: A study in government. Routledge. Retrieved from https://goo.gl/Go3o1S.
[6] Luciani, F. G. (2015). Allocation vs. production states: A theoretical framework. In The rentier state, 77-96, Routledge. Retrieved from https://goo.gl/1gyrLd.

[7] McKerchar, M. A., \& Evans, C. (2009). Sustaining growth in developing economies through improved taxpayer compliance: Challenges for policy makers and revenue authorities. Retrieved from https://goo.gl/U3C3rz.

[8] Murphy, L., \& Nagel, T. (2002). The myth of ownership: Taxes and justice. Oxford University Press. Retrieved from https://goo.gl/ Ker4XC.

[9] Ölz, S., \& Beerepoot, M. (2010). Deploying Renewables in Southeast Asia. Retrieved from https://goo.gl/8vAsa8.

[10] Talmadge, P. A. (2000). The myth of property absolutism and modern government: The interaction of police power and property rights. Wash. L. Rev., 75, 857. Retrieved from https://goo.gl/xsf3XA. 